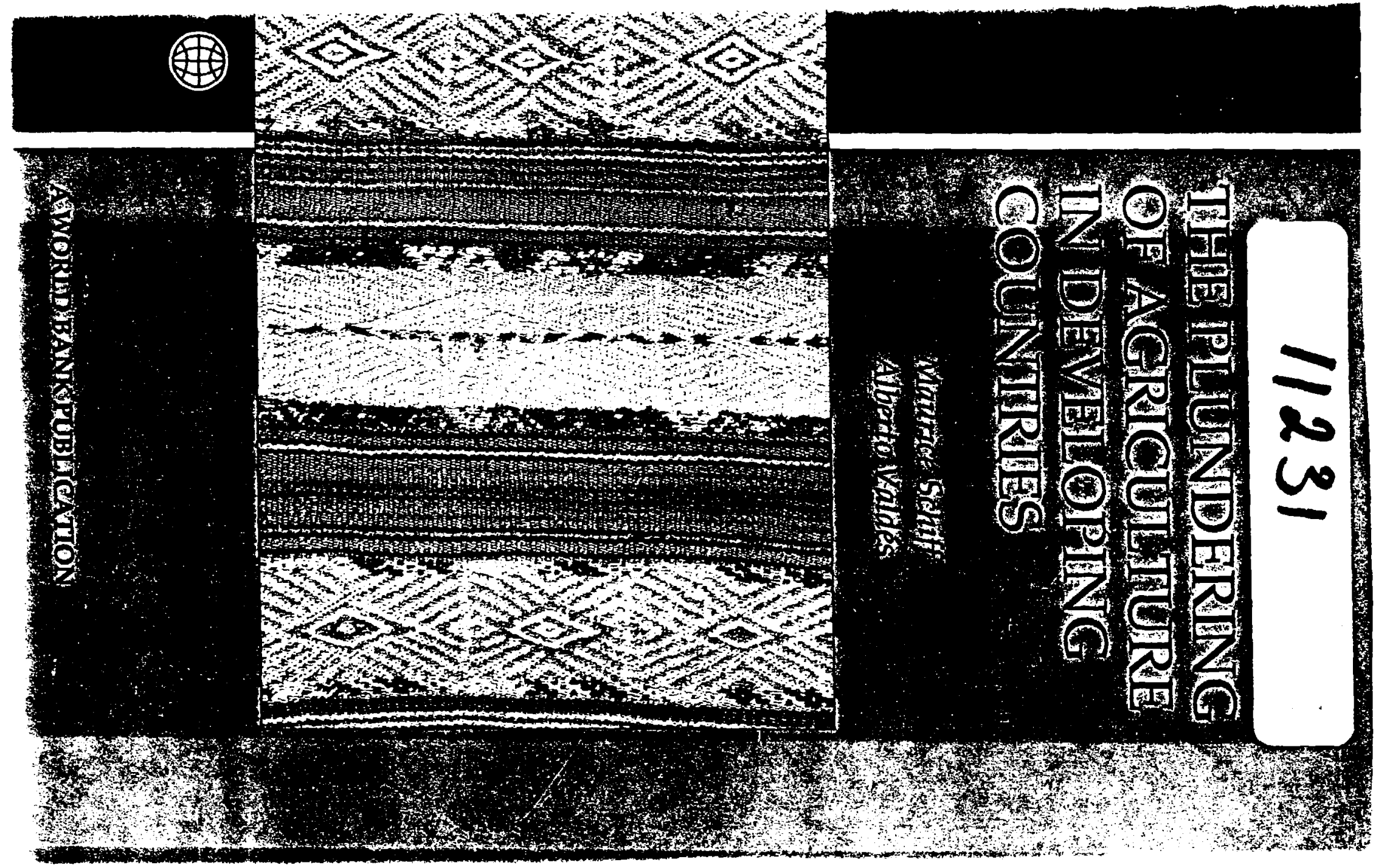





\title{
The Plundering of Agriculture in Developing Countries
}

\author{
Maurice Schiff \\ Alberto Valdés
}


(C) 1992 The International Bank for Reconstruction and Development / THE WORLD BANK

1818 H Street, N.W.

Washington, D.C. 20433

All rights reserved

Manufactured in the United States of America

First printing September 1992

The findings, interpretations, and conclusions expressed in this study are entirely those of the authors and should not be attributed in any manner to the World Bank, to its affiliated organizations, or to members of its Board of Executive Directors or the countries they represent.

The cover photograph shows a detail of a poncho from Cuzco, Peru, typical of those worn by Quechua farmers.

Library of Congress Cataloging-in-Publication Data

Schiff, Maurice W.

The plundering of agriculture in developing countries / Maurice

Schiff, Alberto Valdés.

p. $\mathrm{cm}$.

Includes bibliographical references.

ISBN 0-8213-2184-6

1. Agriculture-Economic aspects-Developing countries.

I. Valdés, Alberto, date. II. Title.

HD1417.S32 1992

$338.1^{\prime} 09172^{\prime} 4-\mathrm{dc} 20$ 


\section{Contents}

Preface $v$

The Average Tax on Agriculture Was Huge 4

The Transfers Out of Agriculture Have Been Enormous 7

Agricultural Growth Was Slowed by Taxation 8

Economic Growth Was Slowed by Agricultural Taxation 10

Farmers Do Respond to Price Incentives 12

Price Interventions Affect the Budget in Many Ways 14

The Contribution to Revenue Can Be Considerable 15

Price Distortions in Agriculture Have Increased 18

Direct Interventions Raised the Cost of Food to Urban Consumers Somewhat 20

Direct Interventions Reduced the Variability in Producer Prices

Direct Interventions Stabilized the Prices of Staples More Than Those of Other Products 25

Direct Interventions Reduced the Variability in Consumer Prices in Most Countries 25

For Urban Consumers, the Short-Run Income Losses Were Small in Most Countries 26

For the Rural Poor, the Short-Run Income Losses Were Substantially Larger 28

In the Long Term, the Poor Have Probably Lost Disproportionately 29 
What Happens If Many Developing Countries Reform

Agricultural Prices at the Same Time?

Price and Trade Reform Lessons

\section{References 36}




\section{Preface}

The findings and policy implications presented in this booklet are based on a World Bank comparative study of agricultural pricing policies in developing countries, which examined agricultural pricing interventions in eighteen developing countries during 1960-85. The results of the study have been published in a five-volume series, The Political Economy of Agricultural Pricing Policy (Baltimore, Md.: Johns Hopkins University Press). Volumes 1, 2 and 3 are regional; 1 is on Asia, 2 is on Latin America, and 3 is on Africa and the Mediterranean (all were edited by Anne O. Krueger, Maurice Schiff, and Alberto Valdés). Volumes 4 and 5 are syntheses. This booklet draws mainly on the findings of volume 4, A Synthesis of the Economics in Developing Countries (by Maurice Schiff and Alberto Valdés). Volume 5 is A Synthesis of the Political Economy in Developing Countries (by Anne O. Krueger). The authors would like to thank Bruce Ross-Larson for his excellent editorial work and Harold Alderman, Johannes Linn, and Michel Petit for their useful comments. 

Industry has been the darling of development, certainly for the nowindustrial countries, and more recently for the developing countries. Those with the reins of policy in developing countries decided that agriculture was impervious to price incentives, so they believed that taxing it would sacrifice little in output-or so went the conventional wisdom. Moreover, agricultural taxes were easy to administer and extremely attractive in countries with a thin tax base. In addition, shifting scarce resources to industry was thought to be justified by agriculture's declining terms of trade-a pound of agricultural exports was buying less and less than a pound of industrial imports - and by the rising protection in industrial countries. So policymakers taxed the daylights out of agriculture, secure that they were doing the right thing. (The term taxation refers here to reductions in the domestic prices of agricultural products and is not synonymous with, but does not exclude, explicit taxation that generates government revenues. In addition, the issues of income and property taxes are not dealt with here.)

By the 1980s this conventional wisdom was beginning to look less wise. It was becoming apparent that far more than agricultural price policy was influencing the decisions of farmers to invest and to produce-unsavory shifts in the exchange rate, for example. It was also becoming apparent that taxing agriculture was sacrificing far more in output than surmised earlier.

Above all, however, the conventional wisdom had never been put to a rigorous test-until the research in eighteen developing countries reported here (see box 1 ). This research asked two basic questions: Is agriculture really that unresponsive to price incentives? And can countries develop faster and at lower cost by taxing agriculture? To find out, we examined how price interventions affect agricultural growth and overall economic growth-and we measured the income transfers that price interventions induced among agriculture, government, and the rest of the economy. To see whether controls on food prices helped the poor, we studied the effects of price interventions on the incomes of the rural and urban poor in the short run-and in the long run. And to see whether the policies for the prices of agricultural commodities kept them stable, we separated the effects of those policies from the effects of other forces determining commodity prices. This may seem to be a straight- 


\section{Box 1. The Test-and Demolition-of Conventional Wisdom}

Research on development strategies and trade regimes in developing countries since the early 1970 s has consistently found that countries that have adopted outward-oriented strategies have been more successful than countries that sought to build their industrial sector through inwardoriented strategies of import substitution (Little, Scitovsky, and Scott 1970; Balassa 1971; Bhagwati 1978; Krueger 1978, 1983; and Krueger, Lary, and Akrasanee 1981). But none of these comparative studies explicitly examined agriculture or looked systematically at the impact of trade and balance of payments regimes or other types of indirect intervention on agricultural incentives.

Studies that have examined agriculture have been narrow or have relied on different methods, making cross-country comparisons difficult at best. Such well-known comparative studies of agricultural price policies as the Stanford Food Research Institute's examination of rice policies in Asia (1975) and the World Bank's case studies of administered agricultural prices, taxes, and subsidies (1976) deal essentially with sectoral output and input price policies. Many individual country studies have estimated the short-term effects of sectoral policies on agricultural output, food consumption, and trade flows. A few others have also explored the political factors influencing agricultural price policies in individual countries. One set of studies by the International Food Policy Research Institute did examine some of the interactions between industrial protection and agricultural incentives. But it did not analyze all those interactions. Nor did it analyze the indirect effects of macroeconomic policies, the quantitative effects of these policies, or the underlying political economy.

The World Bank research reported here fills these gaps by assessing the effects on agriculture of both direct and indirect price interventions during twenty-five years in eighteen representative developing countries, using a common conceptual framework and methodology. The research developed measures of the impact of direct and indirect price policy interventions on relative prices within agriculture and between agriculture and the rest of the economy. These measures were then used to estimate the effects of price interventions on agricultural production, consumption, foreign exchange earnings, the budget, income transfers between agriculture and the rest of the economy, and income distribution. In the context of the history of agricultural price interventions in each country, these estimates also provided a basis for analyzing the evolution of the country's political economy of agricultural price policies.

Someother issues-also important for agricultural policy-were not the central focus of this study. They include optimal investment in agriculture, 


\section{Box 1 (continued)}

optimal taxation of agriculture, and agriculture's role in a country's overall development strategy. These issues are important, but they cannot be examined in an analysis that focuses on a specific sector of the economy, as this one does. They require a broader analytical framework.

Here, in a nutshell, are our most striking findings:

- The indirect tax on agriculture from industrial protection and macroeconomic policies was about 22 percent on average for the eighteen countries during 1960-85-nearly three times the direct tax from agricultural pricing policies (about 8 percent). The total (direct plus indirect) was thus 30 percent.

- Industrial protection policies taxed agriculture more than did real overvaluation of the exchange rate.

- High taxation of agriculture was associated with low growth in agriculture-and low growth in the economy.

- Surprisingly, most countries protected importables. On average, the direct protection of importables was about 18 percent and the direct taxation of exportables about 16 percent, for an average impact (on the relative price of importables to exportables) of about 40 percent. These distortions within agriculture increased between the early 1960 s and the mid-1980s.

- Direct price policies stabilized domestic agricultural prices relative to world prices, with an average reduction in variability of 25 percent and even more when world prices were highly volatile. Indirect policies contributed little, if anything, to price stability.

- Public investment in agriculture did not compensate for adverse price policies.

- The effect of removing agricultural price interventions is not regressive. In most countries, removing direct (or total) interventions changed the real incomes of the poorer urban and rural groups by less than 5 percent (up or down). More often than not, the rural poor gained from removing the interventions.

- The contribution of agriculture to fiscal revenues has fallen over time and is on average small.

forward line of inquiry, but it was no small task for a twenty-five-year period in eighteen countries.

The findings provide a solid base for prescribing agricultural price policy in the developing countries. If a country wants to prosper, it should not tax agriculture relative to other sectors (the exceptional case of optimal trade taxes is discussed in the last section). But to stop taxing 
agriculture, the country must do more than dismantle the interventions in agricultural prices-it must, in addition, eliminate other taxes on agriculture, including the protection of industry and getting the exchange rate in line with its long-run equilibrium value. And if it stops taxing agriculture, it must (or at least many countries must) look to other sources of revenue to finance the activities of government. It is also essential within the agricultural sector to stop taxing exports and protecting imports (to put imports and exports on an equal footing) -and to dismantle quotas, licenses, and state trading companies (which obscure the real winners and losers from subsidies or taxes), and those internal agricultural marketing regulations that prevent a free flow of goods and services within the country.

Nor should governments use social objectives (like protecting the poor) to justify tampering with agricultural prices. The reasons? The impact on the poor is minuscule in the short run in most countries and impossible to know in the long run. Moreover, agricultural growth-and incomes-will suffer. And what about the advantages of stable commodity prices for producers? They get subverted, quickly, by strong agricultural interests that use price stabilization programs to raise prices of importables and by governments that use them to raise revenues by taxing exports-to everyone else's detriment. It is far better, therefore, to reform broader agricultural policies and to develop efficient riskmanagement instruments. And to reap the full benefit of reforming agricultural prices and agricultural trade, it helps to launch simultaneous reforms outside agriculture-in land, in finance, in transport, and in communication. These points lead to two policy recommendations:

Policy recommendation 1. If a country wants to achieve faster agricultural growth, faster economic growth, and fewer poor people, it should stop taxing agriculture relative to other sectors.

Policy recommendation 2. To stop taxing agriculture, a country should eliminate the undue protection of industry and the overvaluation of the exchange rate (three-fourths of the tax)-and dismantle the interventions in agricultural prices (one-fourth of the tax).

\section{The Average Tax on Agriculture Was Huge}

Governments influence agricultural prices both directly, through agricultural sector policies, and indirectly, through industrial protection and macroeconomic policies that tax agriculture relative to tradables and nontradables outside the agricultural sector. Indirect interventions depress the 
prices of agricultural tradables relative to nontradables (through their impact on the real exchange rate) and relative to other tradables (due to industrial protection). These policies affect production incentives by making agriculture less attractive than other sectors of the economy. The effects of indirect interventions have until recently been outside the theoretical and political debate on agricultural price interventions in developing countries.

What have been the effects of such direct and indirect interventions in eighteen developing countries during twenty-five or so years? On average, they taxed agricultural producers by about 30 percent (table 1 ).

The indirect effects (22 percent tax) were by far the stronger, easily outweighing even the positive influence of direct interventions in the few cases where direct measures protected agriculture. Macroeconomic policies caused the appreciation of the real exchange rate, raised the relative cost of nontradable inputs, and reduced the real purchasing power of income received from the sales of export- and import-competing commodities. Moreover, protection for domestic industry hurt agriculture by raising the domestic price of importable agricultural inputs above world prices, by reducing the purchasing power of farm households as consumers of manufactured goods, and by causing further appreciation of the real exchange rate. Such intervention usually reduced agriculture's share of gross national product and was often related to slower growth in agricultural production and agricultural exports and to slower economic growth overall.

Many direct measures have also taxed agriculture - on average, by 8 percent-depressing the prices received by agricultural producers. Governments intervened directly through procurement measures (government marketing boards are often the only legal buyers of agricultural outputs), quotas on exports of food crops and other agricultural commodities, and direct taxation of such exports. But some direct measures benefited agricultural producers. Governments often subsidized the costs of farm credit and important agricultural inputs, such as fertilizer. Many developing countries, to increase their food self-sufficiency, protected domestic producers of import-competing food products through quantitative restrictions or tariffs on imported commodities. And some countries, responding to the instability of world markets, intervened to stabilize domestic producer prices relative to prices on world markets.

Yet other direct measures attempted to hold down the costs of food for urban consumers-by fixing retail food prices or imposing ceilings on producer prices. Sometimes governments set up dual pricing systems to keep producer prices high and consumer prices low, making up the difference out of budgetary resources. Although the fiscal costs of food 
Table 1. Direct and Indirect Taxation of Agriculture in Eighteen Countries, 1960-84

(period average in percent)

\begin{tabular}{|c|c|c|c|c|c|}
\hline Country & Period & $\begin{array}{c}\text { Indirect tax } \\
\text { (negative } \\
\text { protection) }\end{array}$ & $\begin{array}{l}\text { Tax due to } \\
\text { industrial } \\
\text { protection }\end{array}$ & $\begin{array}{l}\text { Direct } \\
\operatorname{tax}\end{array}$ & $\begin{array}{c}\text { Total } \\
\text { tax }\end{array}$ \\
\hline Extreme taxers & $1960-84$ & 28.6 & 25.7 & 23.0 & 51.6 \\
\hline Côte d'Ivoire & $1960-82$ & 23.3 & 23.2 & 25.7 & 49.0 \\
\hline Ghana & $1958-76$ & 32.6 & 32.4 & 26.9 & 59.5 \\
\hline Zambia & $1966-84$ & 29.9 & 21.4 & 16.4 & 46.3 \\
\hline Representative taxers & $1960-86$ & 24.2 & 32.8 & 12.0 & 36.4 \\
\hline Argentina & $1960-84$ & 21.3 & 39.5 & 17.8 & 39.1 \\
\hline Colombia & $1960-83$ & 25.2 & 37.8 & 4.8 & 30.0 \\
\hline Dominican Republic & $1966-85$ & 21.3 & 20.8 & 18.6 & 39.9 \\
\hline Egypt & $1964-84$ & 19.6 & 27.5 & 24.8 & 44.4 \\
\hline Morocco & $1963-84$ & 17.4 & 13.4 & 15.0 & 32.4 \\
\hline Pakistan & $1960-86$ & 33.1 & 44.9 & 6.4 & 39.5 \\
\hline Phílippines & $1960-86$ & 23.3 & 33.0 & 4.1 & 27.4 \\
\hline Sri Lanka & $1960-85$ & 31.1 & 40.1 & 9.0 & 40.1 \\
\hline Thailand & $1962-84$ & 15.0 & 13.9 & 25.1 & 40.1 \\
\hline Turkey & $1961-83$ & 37.1 & 57.4 & -5.3 & 31.8 \\
\hline Mild taxers & $1960-83$ & 15.7 & 22.9 & 0.2 & 15.8 \\
\hline Brazil & $1969-83$ & 18.4 & 21.4 & -10.1 & 8.3 \\
\hline Chile & $1960-83$ & 20.4 & 37.4 & 1.2 & 21.6 \\
\hline Malaysia & $1960-83$ & 8.2 & 9.9 & 9.4 & 17.6 \\
\hline Protectors & $1960-84$ & 13.6 & 13.9 & -24.0 & $-10,4$ \\
\hline Korea, Republic of & $1960-84$ & 25.8 & 26.7 & -39.0 & -13.2 \\
\hline Portugal & $1960-84$ & 1.3 & 1.0 & -9.0 & -7.7 \\
\hline Sample average & & 22.5 & 27.9 & 7.9 & 30.3 \\
\hline
\end{tabular}

subsidies could be reduced by carefully targeting programs, such programs sometimes proved impractical in low-income developing countries because of their complex administrative demands and the large size of the target groups. Explicit food subsidies often proved unsustainable (as in Sri Lanka), because of budgetary and balance of payments pressures, so some governments instead either reduced consumer prices by taxing agricultural producers or drastically reduced consumer subsidies. 


\section{The Transfers Out of Agriculture Have Been Enormous}

In most industrial countries, the main objective of agricultural price policies is to maintain farm income and employment in the face of declining real world prices for cereals-with massive net income transfers to agriculture. In most developing countries, however, the primary objectives have been food self-sufficiency, domestic price stability, low food prices for urban consumers, and government revenue. On average the net effect of direct and indirect interventions has been an enormous income transfer out of agriculture-averaging 46 percent of agricultural gross domestic product (GDP) a year during the period 1960-84. These transfers ranged from 2 percent for the protectors to 140 percent for the extreme taxers. The average for the representative taxers was 37 percent. Such enormous transfers must have severely depressed private investment in agriculture and agricultural growth.

An analysis of these income transfers-and of who gained and who lost from them-helps to reveal some of the motives for price interventions and to identify the forces arrayed against reform. Agriculture was clearly the loser, while the big winners were government (net revenue gain), urban consumers (lower food prices), and industry (cheap raw materials and other inputs).

The average net income transfer out of agriculture as a result of direct price interventions was 4 percent of agricultural GDP during 1960-84 for the selected products in our sample countries: direct price interventions on outputs reduced agricultural GDP by about 6 percent, and transfers into agriculture through input subsidies boosted agricultural income by about 2 percent. (This calculation understates the true transfer out of agriculture because it includes output transfers only for the selected products but includes input subsidies for all agriculture). Expanding the output coverage to the rest of agriculture raises to 19 percent the average net transfer out of agriculture as a result of direct price interventions. Adding the transfers into agriculture from nonprice-policy-related interventions ( 7 percent) results in a total net income transfer out of agriculture as a result of direct interventions of about 4 percent (the average of the results under the two sets of output coverage).

Taking into account the income effects of indirect price interventions raises the net transfers out of agriculture to an astounding 46 percent of agricultural GDP. For the representative taxers, total transfers out of agriculture averaged 37 percent of agricultural GDP. For the extreme taxers, the income effects of total interventions were staggering: if agricultural GDP had a value of 100 under total price interventions, it would 
have reached 240 if there had been no price interventions over the period.

Also important is what we did not find. Input subsidies did not compensate, or compensated very little, for the substantial income outflows resulting from interventions in output markets, and in most cases, public investment in agriculture did not compensate for the negative effects of price interventions. For the representative taxers, the income transfer through input subsidies was never higher than 1.1 percent of agricultural GDP, and for all eighteen countries, the average for 1960-84 was only 2 percent (for direct interventions). Higher investment by government to compensate for taxing agriculture was found, to varying degrees, in only five of fifteen cases, with only Egypt and Morocco showing compensation for all agricultural price policy or income variables tested.

In sum: government and the nonagricultural sectors were the winners in most cases, and agriculture the loser. In the most frequent case, the government earned net revenues from direct price interventions (or transferred resources out of agriculture), supporting the hypothesis that the extraction of resources was a frequent objective of direct price interventions and resulted in a strong antiexport bias in the trade regime.

\section{Agricultural Growth Was Slowed by Taxation}

To examine the impact of price policy on annual growth of real agricultural GDP, we compared the average agricultural growth rate in the group of countries in which nominal "taxation" rates were lower (nominal protection rates were higher) than the average with the rate in the group in which taxation rates were higher (protection rates were lower) than the average. The group with the lower taxation rates (higher protection) showed a higher average growth rate, a result that is statistically significant. We also used a regression estimate of the growth rate of real agricultural GDP to simulate its average growth rate in the absence of total price interventions. Here, too, the relationship between total taxation (protection) and agricultural growth was significant: the lower the tax on agriculture, the higher the growth. The higher prices in agriculture reduce labor outmigration from the sector, increase investment, and encourage wider adoption of new techniques-and result in a higher growth rate.

For the high and low direct taxation (protection) groups, the difference in mean agricultural growth is small-1 percentage point, or 30 percent-and statistically not significant. But for the two total taxation (protection) groups, the difference is large-2.5 percentage points, or 90 
Table 2. Agricultural Protection (Mostly Negative) and Agricultural Growth (percent)

\begin{tabular}{lcclcc}
\hline \multirow{2}{*}{ Variable } & \multicolumn{2}{c}{ Direct intervention } & & \multicolumn{2}{c}{ Total intervention } \\
\cline { 2 - 3 } & \multicolumn{2}{c}{ High } & Low & & \multicolumn{2}{c}{ High } & Low \\
\hline $\begin{array}{l}\text { Nominal protection } \\
\text { rate }\end{array}$ & 10.8 & -29.3 & & -8.3 & -46.2 \\
$\begin{array}{l}\text { Annual agricultural } \\
\text { growth rate }\end{array}$ & 4.3 & 3.3 & & 5.2 & 2.7 \\
\hline
\end{tabular}

percent--and significant (table 2). This provides strong evidence of an association between high total taxation and low rates of agricultural growth, but weaker evidence of such an association for the direct taxation rate. The finding seems to confirm that total (direct plus indirect) intervention rather than direct intervention is the relevant concept when examining differences in agricultural growth performance-because it also captures the substantial impact of industrial protection and exchange rate misalignment. Direct intervention, although used more commonly, captures only a small fraction of the impact of price interventions on agricultural incentives (about a quarter of the total impact, on average).

There are other reasons why total (direct and indirect) price interventions might be more strongly associated with growth in real agricultural GDP than direct interventions alone. The relation of interest is that between agricultural growth and agricultural incentives. Since indexes of agricultural incentives (relative prices) cannot be compared across countries, we used protection rates instead. And differences in total taxation rates tend to reflect differences in agricultural incentives more closely than do differences in direct taxation rates.

This is so for several reasons. First, direct price interventions are used in part to stabilize domestic prices, and so rates of direct taxation (negative protection) tend to move inversely with border prices. Consequently, changes in direct taxation rates do not always reflect changes in producer prices. Indirect taxation rates, by contrast, would not be expected to be closely related to agricultural border prices, so changes in total taxation (negative protection) tend more closely to reflect changes in producer incentives. This is confirmed by the finding that most of the reduction in producer price variability (relative to that of border prices) is due to direct price interventions, with indirect price interventions having a negligible impact.

Second, the impact of direct intervention on agricultural GDP might be ambiguous. Some of the impact could be due to changes in output mix, 
since the impact of direct price interventions varies by product or product group-some are taxed and others are protected. So the impact of low average direct taxation may be more important if it affects relative prices within agriculture more than a policy with higher but more uniform direct taxation. This is less likely to occur with indirect intervention: industrial protection policies reduce relative incentives for the entire agricultural sector, and overvaluation of the real exchange rate taxes all tradable agricultural products, which constitute the bulk of the agricultural sector in most countries.

Third, changes in direct intervention are not always positively correlated with changes in total intervention. And the latter constitute a better measure of the impact of intervention on agricultural incentives than the former. It should be no surprise, then, that agricultural growth is more strongly associated with the sum of direct and indirect interventions than with direct intervention alone.

\section{Economic Growth Was Slowed by Agricultural Taxation}

The high tax on agriculture in many developing countries has been motivated in part by the belief that industry was the dynamic sector while agriculture was static and not very responsive to incentives. So economic growth would be accelerated by shifting resources from agriculture to industry. This resource shift was to be achieved by taxing agriculture indirectly - by protecting the industrial sector and maintaining an overvalued real exchange rate-and directly. Several of the country studies explicitly mention such an industrialization strategy: Argentina, Chile, Colombia, the Dominican Republic, Ghana, Malaysia, Morocco, Pakistan, and Zambia. And most of the others suggest that such a policy was implicit in increasing government revenue by taxing agriculture and using it to increase spending outside agriculture.

These policies did not accelerate growth, however. We examined the relation between price interventions and overall economic growth in three ways. First, we compared the various measures of intervention with the rates of growth of GDP across four groups of countries. Second, we used regression analysis to relate the various measures of intervention to GDP growth for the eighteen countries. Third, we examined the relation between the various measures of intervention and GDP growth for the eighteen countries, dividing them into two groups based on the average size of the various measures of intervention.

All three tests suggest a negative relation between the rate of total taxation of agriculture and GDP growth: policies that depress agriculture's terms of trade below international levels are associated 
with slower economic growth. We also found that GDP growth rose as the indirect taxation of agriculture fell across the four country groups. The analysis showed that greater exchange rate overvaluation was related to lower GDP growth-and the stronger the industrial protection, the lower the GDP growth.

Comparisons of price interventions and GDP growth for the four country groups show that higher rates of indirect and total taxation have been associated with lower economic growth (table 3). The GDP growth rate for the least interventionist group (the protectors) is twice as large (6.5 percent) as that ( 3.3 percent) for the most interventionist group (the extreme taxers). We cannot claim causality from higher taxation to slower growth, but this inverse relation between taxation and GDP growth is confirmed by the other two tests.

In examining the relation between GDP growth and intervention, we also looked at whether the average GDP growth rate was significantly lower for the countries with higher-than-average values of intervention measures than for the other countries. Indeed, GDP growth does fall with increases in the rates of total taxation (significant), in indirect taxation (not significant), and in industrial protection (significant).

The results show that policies that lower agriculture's domestic terms of trade below their international level are associated with a slowdown in economic growth-precisely the opposite of the intended effect from industry-led growth strategies that tax agriculture through direct and indirect interventions. The belief that economic growth could be accelerated by shifting resources from agriculture to industry rested on the premise that agriculture was a static sector, and it received further support from the prevailing pessimism about the prospects for agricultural exports. These were misperceptions from which both agriculture and the economy as a whole may have suffered in many developing countries.

Table 3. Price Interventions and GDP Growth, by Country Group, 1960-85 (percent)

\begin{tabular}{|c|c|c|c|}
\hline \multirow[b]{2}{*}{ Country group } & \multicolumn{2}{|c|}{ Nominal rate of protection } & \multirow{2}{*}{$\begin{array}{c}\text { Annual } \\
\text { GDP growth }\end{array}$} \\
\hline & Indirect & Total & \\
\hline Extreme taxers & -28.6 & -51.6 & 3.3 \\
\hline Representative taxers & -24.4 & -36.4 & 5.1 \\
\hline Mild taxers & -15.7 & -15.8 & 5.3 \\
\hline Protectors & -13.6 & 10.4 & 6.5 \\
\hline
\end{tabular}




\section{Farmers Do Respond to Price Incentives}

There has long been a presumption that the production of individual agricultural products responds quickly to higher prices-because of shifts between products-but that total agricultural production is slow to respond. The presumption is wrong.

We have already shown that price interventions in the eighteen countries studied severely depressed agricultural prices during 1960-84. Total taxation averaged more than 30 percent, reaching almost 40 percent or more in more than half the countries. Direct price interventions reduced agricultural prices by an average of 8 percent, with the prices of exportables declining by more than the average and those of importables rising somewhat. Indirect price interventions led to huge reductions in agriculture's domestic terms of trade in most of the eighteen countries, averaging 22 percent. Without price interventions, agriculture's terms of trade would have been more than 40 percent higher during 1960-84.

With such a large price impact from intervention, the effect of price reform on output is likely to be significant. How agricultural production responds to a price reform depends on how severely interventions have depressed prices, how extensive and credible the reforms are, how responsive output is to a given price change, and what time period is considered. Clearly, some of these elements are related. Responsiveness to a given price change depends on the credibility of the reform, while credibility may depend on the extent and nature of the price reform.

Aggregate output can expand even in the short run-through increased use of agricultural labor, capital, and variable inputs. The real value of agricultural GDP can also expand through the reallocation of agricultural labor, capital, and land to more productive uses in response to changes in relative agricultural prices. A price reform that affects relative prices within agriculture will induce a change in output mix. And the reallocation of a given set of resources to more productive uses within agriculture will generate real income gains.

This can be illustrated with a simple example. On average, direct price interventions protected importables and taxed exportables, resulting in a net direct tax for the agricultural sector. Removing direct price interventions, then, would increase the price of exportables, reduce the price of importables, and lead to a net increase in prices for the sector. In other words, the sector would gain in the value of output. That is not the entire gain, however, because agricultural producers can move resources to the products whose relative price increased. In other words, an increase in agriculture's terms of trade leads to a rise in the value of output while 
the change in output mix leads to an additional gain. Those are the short-term gains. Further increases in aggregate output are possible beyond those resulting from increased use of existing resources and changes in output mix. But they require bringing in more labor and capital from other sectors and wider adoption of new techniques. These processes take time.

The efficiency gains from better agricultural price policies depend largely on the aggregate response of the agricultural sector to improved incentives - itself a function of the response of both existing products and new products. Few studies have directly analyzed aggregate supply response. Instead, much of the empirical work on supply response has dealt with individual products or groups of related products. Most of the debate, by contrast, has dealt with the aggregate response over time. The issue is important because if the aggregate response of agriculture is low, the cost of taxing agriculture is also low. We believe that the methods used to estimate the aggregate supply response have often severely underestimated that response. Estimating the long-run aggregate supply response requires an economywide perspective that takes into account intersectoral resource movements in response to changes in incentives across sectors. A few studies have done this, and they find that labor migration and investment respond to agriculture's terms of trade.

Policy recommendation 3. If the revenues from direct price interventions in agriculture provide a big share of government revenues, a country should reform its tax system to replace the revenues lost from no longer taxing agriculture.

The fiscal effects of specific agricultural price policies have received much attention and generated intense debate. But there have been few (if any) systematic attempts to quantify the net fiscal impact of price interventions. Consumer food subsidies have frequently been cited as a major drain on government budgets. But while they may be a drain for some food-importing countries, they are not for most countries. Similarly, many countries have a tradition of subsidizing agricultural credit and inputs, conventionally interpreted as compensating producers for the heavy taxation of agricultural production. Yet such subsidies represent only a small part of government expenditure (averaging only about 2 percent over 1960-83) while taxing agricultural exports yields substantial revenue to the government (averaging 10 percent of government expenditure). Indeed, the net effect of direct price interventions in agriculture was a revenue gain to the government of nearly 7 percent over the period-and as much as 17 percent during the 1960s. 


\section{Price Interventions Affect the Budget in Many Ways}

Most direct agricultural price interventions affect the government accounts. The effects of some interventions-such as outlays for agricultural input and production subsidies or revenues from explicit border taxes-are obvious. The effects of others-such as the effects of price interventions on the operating deficits or surpluses of state-owned marketing boards-are more complex or even hidden. Whatever the price intervention, it is likely to have some fiscal impact, and that fiscal impact influences agricultural price policy.

This dynamic relationship between price policy and fiscal policy is especially clear in agricultural export policy and food and input subsidies. The government's need for revenue to fund expanding development programs was probably the major impetus behind taxing agricultural exports, and it remains the major constraint to reform. The government revenues from the export operations of the Cocoa Marketing Board in Ghana and from the export tax on grains and beef in Argentina are examples of the importance of the revenue motive-and the obstacles it poses for reform. In some countries, the fiscal burden of input and food subsidies escalated so rapidly that it led to macroeconomic imbalances that could be corrected only through policy reform. Changes in agricultural policies in Portugal were dictated chiefly by budget pressures in the early 1980s, when fertilizer and feed subsidies were essentially eliminated. Attempts to reduce food subsidies in Egypt, Morocco, and Pakistan also show the link between price policy and the budget.

In most industrial countries, the major impetus for the reform of agricultural programs now comes from fiscal pressures, even though income transfers seem to be the primary objective of agricultural policies in these countries. In developing countries, by contrast, the links between price policies and the government budget arise mainly through the contribution of agricultural exports to fiscal revenues and the cost of government outlays for food subsidies to urban consumers.

This analysis of the budgetary effects of price policies considers only direct price interventions in agriculture. But these effects are only a part of the overall income gains and losses to agriculture from price interventions. Indirect interventions - industrial protection and overvaluation of the exchange rate-generate income transfers to other sectors from agriculture that are off-budget items, many of which yield no revenue to the government. Taxes that apply to other sectors as well as to agriculture, such as income taxes and value-added taxes, have no direct link with agricultural price policies and would continue independent of agricultural price reforms. 
There nevertheless are some indirect links between macroeconomic variables and the budget that could influence the design of direct price interventions. Most of these are difficult to measure and were not included in our calculations of the budgetary effects of price interventions because they were not quantified in most of our country studies. One link involves the nominal exchange rate. For Zambia, especially since 1980, an overvalued exchange rate has resulted in substantial fiscal savings in government operations involving maize and fertilizer imports, given the government's targeted domestic prices for consumers.

Another complex link sometimes arises between farm prices and the government budget in middle-income countries, where agriculture is usually a relatively small sector. In Chile, government lending at concessional rates to the nonfarm private sector was at least partly a compensating mechanism to offset the effects of its agricultural policies. The credit program prevented a decline in nonfarm investment as a result of the substantial rise in nominal urban wages during the 1960s-a consequence of higher farm prices and the downward rigidity of urban real wages due to strong trade unions.

\section{The Contribution to Revenue Can Be Considerable}

In most countries, the net budget effect of price interventions in agriculture was a gain in revenue, mainly through taxes on agricultural exports. For the representative taxers, price interventions in output and input markets during 1960-84 produced revenues of almost 8 percent of government spending (table 4). Output taxes alone produced as much as 20 percent of government spending in the $1960 \mathrm{~s}$. Over time, however, the net contribution of the price interventions for this group of countries fell substantially, from 18 percent of government spending in the 1960s to 5 percent in 1980-84. But in some countries the revenue contribution remains important-and undoubtedly constrains any policy reforms to reduce direct agricultural taxation. In those countries, sectoral reforms that would eliminate or reduce agricultural export taxes would need to be accompanied by economywide tax reform and other fiscal reforms.

Agricultural price interventions resulted in net outlays for a few countries-Brazil, Republic of Korea, Morocco, Pakistan, Turkey, and Zambia- and on average for the mild taxers in 1980-83 and the protectors. In Brazil the net budgetary effects of price interventions varied dramatically, from a revenue gain of 32 percent of government spending during 1966-69 to a net outlay of 43 percent during 1980-83, mainly because of a large increase in credit subsidies to agriculture. 
Table 4. How Direct Price Interventions Affected the Budget, 1960-84

\begin{tabular}{|c|c|c|c|c|c|c|c|c|c|c|c|}
\hline \multirow[b]{2}{*}{ Countrygroup } & \multirow[b]{2}{*}{ Period } & \multicolumn{4}{|c|}{ Output policies } & \multirow[b]{2}{*}{$\begin{array}{l}\text { Total } \\
\text { output } \\
\text { effects }\end{array}$} & \multicolumn{4}{|c|}{ Input policies } & \multirow[b]{2}{*}{$\begin{array}{c}\mathrm{Net} \\
\text { effects }\end{array}$} \\
\hline & & $\begin{array}{c}\text { Export } \\
\text { tax }\end{array}$ & $\begin{array}{c}\text { Import } \\
\text { tax }\end{array}$ & $\begin{array}{c}\text { Produc- } \\
\text { tion } \\
\text { subsidies }\end{array}$ & $\begin{array}{c}\text { Consump- } \\
\text { tion } \\
\text { subsidies }\end{array}$ & & $\begin{array}{c}\text { Credit } \\
\text { subsidies }\end{array}$ & $\begin{array}{c}\text { Input } \\
\text { subsidies }\end{array}$ & $\begin{array}{l}\text { Total } \\
\text { input } \\
\text { effects }\end{array}$ & $\begin{array}{c}\text { State } \\
\text { agency }\end{array}$ & \\
\hline Extreme & $1960 \mathrm{~s}$ & 20.6 & 0.0 & 0.0 & 0.0 & 20.6 & 0.0 & 0.0 & 0.0 & 0.0 & 20.6 \\
\hline \multirow[t]{3}{*}{ taxers } & $1970 \mathrm{~s}$ & 13.2 & 0.0 & 0.0 & 0.0 & 13.2 & 0.0 & 0.0 & 0.0 & -3.0 & 10.2 \\
\hline & $1980 \mathrm{~s}$ & 0.2 & 0.0 & 0.0 & 0.0 & 0.3 & 0.0 & 0.0 & 0.0 & -4.3 & -4.1 \\
\hline & $1960-84$ & 9.4 & 0.0 & 0.0 & 0.0 & 9.4 & 0.0 & 0.0 & 0.0 & -3.4 & 6.0 \\
\hline \multirow{4}{*}{$\begin{array}{l}\text { Representa- } \\
\text { tive taxers }\end{array}$} & $1960 \mathrm{~s}$ & 22.1 & 0.1 & 0.0 & -2.2 & 20.0 & -0.6 & -0.5 & -1.1 & -0.7 & 18.2 \\
\hline & $1970 \mathrm{~s}$ & 12.0 & 0.1 & -0.1 & -2.8 & 9.2 & -0.6 & -0.8 & -1.2 & 0.4 & 8.3 \\
\hline & $1980 \mathrm{~s}$ & 8.6 & 0.0 & -0.1 & -1.7 & 6.8 & -1.3 & -0.8 & -2.1 & 0.0 & 4.8 \\
\hline & $1960-85$ & 11.4 & 0.1 & -0.0 & -2.4 & 9.0 & -0.7 & -0.7 & -1.3 & 0.2 & 7.9 \\
\hline \multirow[t]{4}{*}{ Mild taxers } & 19605 & 15.8 & 0.1 & -0.0 & 0.6 & 16.5 & -3.3 & -0.0 & -3.3 & -0.0 & 13.2 \\
\hline & $1970 \mathrm{~s}$ & 9.4 & 0.3 & 0.1 & -2.1 & 7.7 & -6.7 & 0.0 & -6.7 & 0.0 & 1.0 \\
\hline & $1980 \mathrm{~s}$ & 2.0 & 0.2 & -0.1 & -4.3 & -2.1 & -11.5 & 0.1 & -11.4 & 0.0 & -13.5 \\
\hline & $1960-83$ & 9.3 & 0.2 & 0.0 & -2.0 & 7.6 & -7.1 & 0.0 & -7.0 & -0.0 & 0.5 \\
\hline \multirow[t]{4}{*}{ Protectors ${ }^{b}$} & $1960 \mathrm{~s}$ & n.a. & n.a. & n.a. & n.a. & п.a. & n.a. & n.a. & n.a. & 0.0 & п.а. \\
\hline & $1970 \mathrm{~s}$ & 0.0 & 0.7 & -1.2 & -1.2 & -1.6 & -1.6 & -1.0 & -2.6 & 0.0 & -4.2 \\
\hline & $1980 \mathrm{~s}$ & 0.0 & 1.0 & -0.4 & -0.4 & 0.2 & -1.0 & -0.6 & -1.6 & 0.0 & -1.4 \\
\hline & $1960-84$ & 0.0 & 0.8 & -0.9 & -0.9 & -1.0 & -1.4 & -0.9 & -2.3 & 0.0 & -3.3 \\
\hline \multirow{4}{*}{$\begin{array}{l}\text { Sample } \\
\text { average }^{c}\end{array}$} & $1960-69$ & 19.8 & 0.1 & -0.0 & -1.02 & 18.9 & -1.4 & -0.3 & -1.7 & -0.4 & 16.8 \\
\hline & $1970-79$ & 10.9 & 0.2 & -0.1 & -2.21 & 8.8 & -1.7 & -0.5 & -2.3 & -0.1 & 6.4 \\
\hline & $1980-83$ & 5.8 & 0.1 & -0.1 & -1.90 & 3.9 & -3.0 & -0.5 & -3.6 & -0.5 & -0.2 \\
\hline & $1960-83$ & 10.0 & 0.1 & -0.1 & -1.95 & 8.2 & -1.8 & -0.5 & -2.3 & -0.3 & 6.6 \\
\hline
\end{tabular}


Export taxes, including the profits of state agencies active in exports, were the single most important source of revenue from government interventions in agricultural markets. On average during 1960-84, export taxes amounted to about 10 percent of government spending (20 percent in 1960-69). And in three countries-Brazil, Ghana, and Sri Lanka - export revenues amounted to 20 percent or more of total government spending.

Credit and food subsidies had the next largest impact on the budget, though at less than 2 percent of government spending it was much less than that of export revenues. These subsidies were nevertheless substantial in some countries. Credit subsidies were 20 percent of government spending in Brazil and 4 percent in Colombia. And consumer food subsidies constituted a fairly high share of government spending in Brazil, Egypt, Morocco, Pakistan, and Sri Lanka (table 4).

The interaction between price interventions and budget effects differed systematically for food exporters and food importers. Food exporters such as Argentina and Thailand kept domestic food prices lower than border prices through export taxes and gained revenue in the process. But food importers such as Egypt, Morocco, Pakistan, and Sri Lanka incurred substantial fiscal costs for food subsidies to keep consumer prices low. In most of these countries, food imports generated no revenues because the state agencies with a legal monopoly on staple imports paid no trade taxes-while other agricultural importables were protected through quotas rather than revenue-generating tariffs.

Remember in all this that the revenue and expenditure effects described here were the result of direct interventions only. The net effect of these interventions was to provide revenue to the government, but a far larger impact on agriculture resulted from off-budget items not quantified here-indirect price interventions, most of which do not provide revenue to the government.

Policy recommendation 4. If a country wants to reap the large income gains possible from the reform of agriculture, it should stop taxing agricultural exports and protecting agricultural imports (thus favoring food producers and probably hurting food consumers).

Government price interventions discriminated strongly-and increasingly-against the agricultural sector in developing countries during 1960-84. By far the largest impact came through indirect interventions (industrial protection and macroeconomic policies), which reduced incentives in agriculture relative to other sectors of the economy. On average, direct interventions taxed exportables and protected 
importables, predominantly food products. In most countries, consumer prices for food products moved in the same direction as producer prices in response to direct interventions. So direct interventions, by protecting importables, raised consumer food prices in most cases. Indirect interventions, however, lowered both producer and consumer prices.

Price interventions and their effects are not uniform across product categories-importables (mostly staples) and exportables-in part because of different policy objectives. Taxes on agricultural exports are an important source of revenue for many developing countries, while a desire to reduce a country's dependence on food imports tends to limit taxation of the domestic production of importable commodities, mainly food products.

One would therefore expect to find that exportable products are taxed more than importables. The surprise is that direct interventions have actually protected the production of importables in eleven of sixteen countries (Argentina and Thailand have no important importable products), with an average protection rate of more than 14 percent for the sixteen countries (table 5). In nine of those eleven countries, the average protection rate for importables was above 17 percent, implying that producers received more than 17 percent more for their products than they would have in the absence of direct interventions. (With the usual method of calculating nominal protection rates, direct protection was over 20 percent in those nine countries.) The combined direct and indirect interventions taxed importables at 8.6 percent on average. But direct interventions alone taxed exportables at about 13 percent and the combined direct and indirect interventions tax exportables at about 35 percent on average. This much higher taxation of exportables over importables (in Sri Lanka rice's protection was 84 percent relative to tea) can only have pushed investment decisions the wrong way.

\section{Price Distortions in Agriculture Have Increased}

In most countries, direct taxation (negative protection) rates rose overall from 1973 to 1976 as countries tried (at least partially) to stabilize domestic prices during the world commodity price boom. Direct taxation rates also rose during the boom of 1979-81 in many countries, but by less. On average, the direct tax rose from 4.9 percent to 6.2 percent between 1960-72 and 1976-84.

As expected, the rate of indirect taxation increased from 21.5 percent on average in $1960-72$ to 26.8 percent in $1976-84$, or by 25 percent. The rate increased in twelve of the eighteen countries, with the largest increases in the three Sub-Saharan countries, the extreme taxers. The 
Table 5. Direct and Total (nominal) Protection, by Product Category, 1960-84 (period averages in percent)

\begin{tabular}{|c|c|c|c|c|c|c|c|}
\hline \multirow[b]{2}{*}{ Country } & \multirow[b]{2}{*}{ Period } & \multicolumn{2}{|c|}{ Staples } & \multicolumn{2}{|c|}{ Importables } & \multicolumn{2}{|c|}{ Exportables } \\
\hline & & $\begin{array}{c}\text { Direct } \\
\text { protection }\end{array}$ & $\begin{array}{c}\text { Total } \\
\text { protection }\end{array}$ & $\begin{array}{c}\text { Direct } \\
\text { protection }\end{array}$ & $\begin{array}{c}\text { Total } \\
\text { protection }\end{array}$ & $\begin{array}{c}\text { Direct } \\
\text { protection }\end{array}$ & $\begin{array}{c}\text { Total } \\
\text { protection }\end{array}$ \\
\hline Extreme taxers & $1960-84$ & 18.7 & -9.9 & 17.6 & -11.0 & -20.5 & -49.1 \\
\hline Côte d'Ivoire & $1960-82$ & 26.2 & 2.9 & 26.2 & 2.9 & -28.7 & -52.0 \\
\hline Ghana & $1958-76$ & 46.4 & 13.8 & 42.9 & 10.3 & -29.8 & -62.4 \\
\hline Zambia & $1966-84$ & -16.4 & -46.3 & -16.4 & -46.3 & -3.1 & -33.0 \\
\hline Representative taxers & $1960-86$ & -4.5 & -28.9 & 7.8 & -13.0 & -15.9 & -40.2 \\
\hline Argentina & $1960-84$ & -18.5 & -39.8 & $\ldots$ & $\ldots$ & -17.8 & -39.1 \\
\hline Colombia & $1960-83$ & 9.9 & -15.3 & 14.5 & -10.6 & -8.5 & -33.7 \\
\hline Dominican Republic & $1966-85$ & -18.3 & -39.6 & 19.0 & -2.3 & -24.8 & -46.1 \\
\hline Egypt & $1964-84$ & -24.4 & -44.0 & -5.1 & -24.7 & -32.8 & -51.4 \\
\hline Morocco & $1963-84$ & -15.0 & -32.4 & -8.2 & 25.6 & -18.5 & -35.9 \\
\hline Pakistan & $1960-86$ & 0.6 & -32.5 & -6.9 & -40.0 & -5.6 & -38.7 \\
\hline Philippines & $1960-86$ & -4.6 & -27.9 & 17.4 & -5.9 & -11.2 & -34.5 \\
\hline Sri Lanka & $1960-85$ & 39.0 & 7.9 & 39.0 & 7.9 & -18.4 & -49.5 \\
\hline Thailand & $1962-84$ & -27.6 & -42.6 & $\ldots$ & $\ldots$ & -25.1 & -40.1 \\
\hline Turkey & $1961-83$ & 13.8 & -23.3 & 8.2 & -28.9 & 3.6 & -33.5 \\
\hline Mild taxers & $1960-83$ & 14.2 & -1.5 & 14.2 & -1.5 & 2.1 & -13.6 \\
\hline Brazil & $1969-83$ & 20.2 & 1.8 & 20.2 & 1.8 & 5.4 & -13.0 \\
\hline Chile & $1960-83$ & -1.2 & -21.6 & -1.2 & -21.6 & 13.5 & -6.9 \\
\hline Malaysia & $1960-83$ & 23.6 & 15.4 & 23.6 & 15.4 & -12.7 & -20.9 \\
\hline Protectors & $1960-84$ & 26.9 & 13.3 & 28.4 & 14.8 & 0.5 & -0.8 \\
\hline Korea, Republic of & $1960-84$ & 38.4 & 12.6 & 39.0 & 13.2 & $\ldots$ & $\ldots$ \\
\hline Portugal & $1960-84$ & 15.4 & 14.1 & 17.8 & 16.5 & 0.5 & -0.8 \\
\hline Sample average & $1960-86$ & 6.0 & -16.5 & 14.4 & -8.6 & -12.6 & -34.8 \\
\hline
\end{tabular}


average for that group tripled between the two periods-from 18.5 percent to 55 percent-giving them not only the highest increase between periods but also the highest indirect tax of all groups in 1976-84. Of the countries whose indirect tax fell between 1960-72 and 1976-84, the largest drops came in Chile and Korea, which had introduced broadranging liberalization programs. Overall, total taxation from direct and indirect intervention rose between 1960-72 and 1976-84-from a positive rate of protection of 1.4 percent to a tax of 8 percent for importables and from a tax of 35 percent to a tax of 42.8 percent for exportables. The total tax for all products increased from 26.4 percent to 33 percent.

\section{Direct Interventions Raised the Cost of Food to Urban Consumers Somewhat}

It is commonly believed that developing countries tax agriculture by keeping food prices below their border-price equivalent to appease the more vocal and influential urban consumers and to lower urban wages for the benefit of private and public employers. Our results show, however, that direct price interventions slightly protect food production on average, implying a small tax on food consumption. And with few exceptions (such as Egypt and Zambia), consumption is taxed when food is imported.

Direct protection of food prices-in the thirteen countries for which data were available on the effects of direct and total interventions on consumer food prices-was on average positive and small (6 percent), indicating a small tax on consumers. Direct interventions taxed consumers in Brazil, Ghana, Korea, Portugal, and Turkey. While direct interventions taxed food consumption on average, indirect interventions lowered relative food prices in all countries, implying a subsidy to food consumption relative to nonagricultural prices. Total (direct and indirect) interventions also lowered food prices in all countries except Brazil, Portugal, and Turkey, resulting in an average consumer subsidy of 18 percent.

In all countries (except Sri Lanka) with a rate of direct protection of consumer food prices higher than 5 percent (in absolute value), the rate of direct protection of consumer prices and the rate of direct protection of producer prices for staples have the same sign. That means that when consumption has been taxed, the production of staples has been protected. And when consumption has been subsidized, production has been taxed-so both prices move in the same direction.

In sum: direct price interventions have had a relatively small effect, an 8 percent tax on agriculture on average. But they have had a strong 
effect within agriculture, protecting the production of importables (about 14 percent) and taxing the production of exportables (about 13 percent). Of the indirect interventions, industrial protection has penalized agriculture more than overvaluation of the real exchange rate in two-thirds of the countries examined. The effect of indirect taxation has dominated both direct taxation of exportables and direct protection of importables. Direct price intervention did not lower the cost of food to urban consumers on average-it even raised it somewhat. In most countries that import food, direct intervention has raised prices for both consumers and producers. And in most cases in which direct intervention lowered prices to producers, consumer prices also fell.

Policy recommendation 5. If a country wants to achieve the transparency that's essential for effective price reform-so that it knows whom it is taxing and who is winning and losing-it should dismantle quotas, licenses, and state trading mechanisms.

The analysis of agricultural price interventions in developing countries has two related dimensions. One is defining what constitutes a sectoral (agricultural) price intervention, considering the various forms of domestic assistance to agriculture. The other relates to the influence on agriculture of economywide policies affecting the real exchange rate and industrial protection, and thus the competitiveness of agriculture vis-à-vis other domestic sectors and foreign markets.

Domestic agricultural prices are influenced by such border measures as tariffs and quantitative import and export restrictions, and by nonborder measures as input subsidies, subsidized credit, and irrigation and transport charges. Trade policies are the principal force behind internal agricultural price and income policies; without border barriers on the same products, nonborder policies to protect the production of importables (such as input subsidies) would have a rather limited effect on output and trade flows.

Since World War $\Pi$, in both industrial and developing countries, there has been an upsurge in the proportion of agricultural trade subject to nontariff barriers such as quantitative restrictions, government procurement policies, and technical barriers to trade (including health and sanitary regulations). Many of these nontariff barriers, including state trading, could render unimportant most of the tariffs and explicit export taxes. In industrial countries, the production subsidies for agriculture are widespread. But in most developing countries the most influential price interventions are border measures-and of these, quantitative restrictions (QRs) (rather than tariffs) are the principal policy instru- 
ments. Such QRs include state trading, foreign exchange licenses, quotas on imports, and licenses and quotas on exports.

Dismantling QRS and replacing them with tariffs and explicit export taxes has several important advantages and should be a condition of a trade liberalization package. QRs insulate the domestic market from world price changes. They make the trade and price regime highly discretionary and selective. And they are less visible than tariffs-masking the level of protection or taxation and permitting discretionary interventions. Yet another advantage of replacing QRs with tariffs is that tariffs generate government revenues, removing one of the obstacles to trade reform in some countries. Although declining in importance, revenues from agricultural export taxes have been a significant share of government revenues in several developing countries. And they are still a high share in a few countries. A further advantage is that tariffs would contribute to reducing the role of state trading in agricultural commodities, if they are accompanied by the elimination of the legal monopoly in trade that state agencies have in several countries.

As long as price stabilization remains a paramount policy objective, transparency in agricultural pricing policy may not be achieved as the stabilization mechanism is often subverted into an instrument to transfer resources between producers and consumers or the public sector.

Policy recommendation 6. If a country wants to achieve transparency in agricultural price policy, it may need to develop efficient hedging instruments, eliminate relative price distortions which discourage diversification of the diet, and prevent other motives-such as extraction of revenues or protection of farmers-from subverting the good intentions of price stabilization.

Most developing countries lack the risk-diffusion mechanisms needed to help agricultural producers adapt to highly volatile world prices. That is one reason why many governments intervene to stabilize domestic producer (and consumer) prices - and thereby to stabilize income, to improve production efficiency, and sometimes to redistribute income among the rural, urban, and government sectors. Development of efficient hedging instruments will reduce the need for price stabilization policies.

Distorted relative prices in the past decades have led to excessive concentration in consumption patterns toward one or two staples. Thus, governments became very sensitive to price fluctuations in these key "wage good" food products. Removal of these price distortions should, over time, result in more diversified consumption patterns and thus in 
less pressure to stabilize food prices-and in more flexibility for implementing price reforms.

One macroeconomic argument for price stabilization is that fluctuations in the world price of agricultural exports will lead to fluctuations in export revenues and so to fluctuations in government revenue, the real exchange rate, wages and prices, and other macroeconomic variables. Stabilizing the domestic price of important exportables (say, through a stabilization fund) may partly insulate the economy from external shocks and so reduce macroeconomic instability. Such a policy requires clear and transparent rules so that the pressures from various interest groups cannot subvert the objectives. It is important, however, to distinguish the impact of price stabilization on urban consumers and on farmers and rural consumers-and to distinguish the effects of stabilization of prices, nominal income, real income, and consumption.

A second economywide argument for stabilizing the price of staples that make up a large share in the urban consumer budget is to prevent large fluctuations in urban consumers' real income-in order to avoid fluctuations in (nominal) urban wages. But stabilizing the price of staples may lead to instability in the government accounts. The latter may be as or more economically costly than unstable food prices in the long run, but less politically costly in the short run.

For farmers, there are two principal arguments for stabilizing prices: reducing rural income fluctuations and improving production efficiency. What matters to risk-averse farmers is stabilization of general consumption (or utility) over time. Traditionally, through output diversification and liquidity, farmers have been able to (partly) stabilize consumption but at a cost of reduced average consumption.

Those are the arguments. But what were the actual effects of interventions on price variability?

\section{Direct Interventions Reduced the Variability in Producer Prices}

On average for all countries examined, direct and total interventions stabilized domestic producer prices relative to world prices in each commodity group -importables, exportables, staples, and nonstaples (box 2). Direct and total interventions have tended to reduce year-to-year price variations more than they did price variations around the mean. It seems likely that farmers are more concerned with annual price changes than with price variations around a twenty-five-year average. If so, then the larger reduction in annual price variations (more than 40 percent for direct interventions and more than 50 percent for total interventions on 


\section{Box 2. Suppressing Price Changes}

We asked five questions to see how direct and indirect interventions affected the variability of prices. First, were direct and indirect agricultural price interventions actually successful in stabilizing domestic producer and consumer prices? Yes and no. Second, did direct and indirect interventions have different effects on price variability? Yes. Third, did the price stabilization vary by product group? Yes. Fourth, did the stabilization differ when world prices rose than when they fell? No. And fifth, did the degree of price stabilization differ in the 1960s and in the 1970s and 1980s, when the world prices were more volatile? Again, yes.

To get these answers, we used three measures of price variability: the standard deviation, the coefficient of variation, and the Z-statistic. Each has its merits. The standard deviation measures the degree to which a variable is dispersed around its mean value. The coefficient of variationthe standard deviation divided by the sample mean-standardizes the scale of the variable, so that the degree of dispersion of variables with widely differing average values can be compared. The Z-statistic, a measure of the average deviation of the price from its value in the preceding period (annual price change), is probably a better indicator of producers' concerns-farmers are more likely to be concerned with price deviations from the previous year prices than with deviations from the sample mean.

average) than in variations around the mean would indicate some success in reducing the price risks of special concern to producers.

Total interventions reduced price variability more than did direct interventions, but direct interventions had a far larger impact on price variability than did indirect interventions. Adding the effects of indirect interventions to those of direct interventions somewhat reduces price variability. That indirect intervention did not substantially improve price stability should not be surprising. Real exchange rate overvaluation due to expansive macroeconomic policies (large budget deficits) is usually accompanied by high and variable inflation rates and high relative price variability. Moreover, the main component of indirect intervention is industrial protection, and there is no reason to expect industrial protection policies to reduce relative price variability. Moreover, the world prices of industrial goods are much less volatile than those of agricultural products. In fact, we found that in most countries, indirect interventions resulted in an increase in price variability. 


\section{Direct Interventions Stabilized the Prices of Staples More Than Those of Other Products}

Direct interventions reduced price variability considerably more for staples than for nonstaples. Since both consumers and producers have an interest in price stability for staples, while price stability for nonstaples is of more concern to producers, it is not surprising that direct price interventions stabilized staples more than nonstaples. The same reasoning applies to importables compared with exportables since importables consist mostly of staples and exportables consist mostly of nonstaples. Overall, then, producers of importables (and staples) benefited twice compared with producers of exportables - since producer prices for importables were both more stable and more highly protected by direct intervention.

Did the authorities try to stabilize prices more during commodity price booms than during busts? No. But they did try more price stabilization during periods of high price variability than at other times.

\section{Direct Interventions Reduced the Variability in Consumer Prices in Most Countries}

Direct and total interventions stabilized consumer prices for staples on average for the thirteen countries for which information was available. As with producer prices, price policies stabilized annual price variations more than price variations around the mean. Direct interventions stabilized consumer prices more than indirect interventions, which slightly reduced consumer price variability. The variability of consumer price for staples was reduced in Brazil, Colombia, the Dominican Republic, Egypt, Morocco, the Philippines, Thailand, and Turkey-where price policies also stabilized the producer prices of staples. In the five other countries, consumer price variability increased or the results were mixed.

On the whole, then, price interventions have achieved the objective of stabilizing prices, mainly through direct interventions. Indirect interventions, the major source of agricultural taxation, did little to improve price stability that might have mitigated their harmful overall effects on agricultural incentives. Countries tended to stabilize prices more during the period of volatile world prices in 1971-84 than when world prices were more stable in 1960-70. Producer prices were stabilized more for importable and staple products than for exportable and nonstaple products. Variability was also reduced for staple food prices for consumers in most countries examined. These findings do nothing to support the 
suggestion that the harmful effects of indirect interventions in agriculture are mitigated by any substantial beneficial effects on price variability.

The question is whether the government can provide stabilization at a lower social cost-more efficiently-than the private sector. Many developing countries lack private insurance mechanisms against price risk (such as futures markets or forward contracts)-or such mechanisms are not generally available to small farmers. The governments in those countries may be better able to pool risks. So shifting some of the price risk to the governments may be socially optimal. But the response of farmers and other private agents to government intervention-or the substitutability of private and public stabilization efforts-should also be considered.

Policy recommendation 7. If a country wants to stabilize prices, it should develop efficient hedging instruments, reform agricultural policies, and stop interest groups from subverting the good intentions of price stabilization.

Because low-income families typically spend half or more of their income on food, government policies affecting food prices can have a direct and powerful impact on the living standards of the poor. Providing a regular supply of the basic staples at low prices to consumers is a stated objective of agricultural price policies in most developing countries. But government policies cannot protect all consumers. And faced with budgetary pressures, most governments try to reduce the fiscal burden of food subsidies by transferring part of the cost to producers of farm products, through price controls. So not all low-income groups have benefited equally from price interventions, and some have borne the costs. We find that, in the long run, the net effect of price interventions was in many cases to reduce the real income of the poor more than that of other income groups (box 3).

\section{For Urban Consumers, the Short-Run Income Losses Were Small in Most Countries}

Contrary to the widely held view that cheap food policies prevail in developing countries, the impact of direct price interventions on the real income of urban households during 1960-84 suggests that food price policies penalized urban consumers in six of fourteen sample countries. Most countries protected the production of agricultural importables, mostly food. But only a few of these countries also reduced food prices to consumers through explicit food subsidies. And while direct interven- 


\section{Box 3. How Price Interventions Hurt the Poor}

Price interventions probably hurt the poor in the long run-probably, because the full picture could not be measured. In the long run, indirect interventions affect incomes far more than direct interventions - so governments should not delude themselves into thinking that by tinkering with direct interventions they can redistribute income. In the short run, direct interventions change the incomes of large farmers - up or downfar more than those of small farmers. So, again, governments should not use price interventions for helping poor farmers (targeted income transfers are far superior). In the long run, removing price interventions would raise rural employment and eventually real rural wages-boosting the real income of landless farm workers, the poorest in rural areas and generally in the country.

tions subsidized urban consumers in eight of the fourteen countries, in only four of them (Argentina, Egypt, Pakistan, and Turkey) were the real income effects on both low- and middle-income households higher than 3 percent of their income. Indeed, the income gains or losses from direct interventions were small in most countries for all three income levels. So, despite widespread interventions in food prices, the impact on the real income of urban households was generally small.

For most countries, the income effects of indirect price interventions intensified those of direct interventions. In Argentina, Brazil, Chile, Colombia, the Philippines, Turkey, and Zambia, the effects of indirect interventions were so large that the total effects were at least double the direct effects. Among food exporters like Argentina and Thailand, the effects of subsidies to consumers represented by export taxes on food products were reinforced by the effects of indirect interventions. But in some countries that taxed consumers through direct interventionssuch as Korea, Colombia, and Portugal-the indirect effects led to an implicit subsidy that counteracted the tax in several subperiods (but not so on average for Portugal).

The total income gain for low-income urban consumers ranged from 0.2 percent to 5.3 percent in seven of fourteen countries and was 10 percent or more in three-Argentina, Egypt, and Turkey. Overall, these results confirm that in most countries, the effects of what is commonly referred to as cheap food policies take place mainly through exchange rate misalignment and not through food policies or other direct price interventions. The relatively small effect of direct government interventions on the consumers' mean real income in most countries, together 
with the greater stability of domestic food prices compared with border prices, suggest this: in addition to revenue and self-sufficiency, another big motive underlying food price interventions may have been to prevent sudden large real income losses in years of higher-than-average food prices rather than to raise the standard of living of the urban poor. Unstable world market prices for food products, if passed on directly to consumers, can lead to significant fluctuations in the real income of consumers, a politically sensitive outcome in most developing countries.

\section{For the Rural Poor, the Short-Run Income Losses Were Substantially Larger}

Differences in consumption patterns, production mix, and marketable surplus as a proportion of farm output account for most of the differences in income effects among farm (or rural income) categories. The results are for the short-term effects only-at given levels of production and given consumption patterns.

In Ghana and Korea, and less so in Brazil, small farmers (or poorer households) benefited from direct price interventions. In Ghana, direct interventions benefited small farmers and taxed large farmers, while in Korea and Brazil, large farmers benefited even more than small farmers. Ghana was the only country of seven analyzed in which the income effects (as a percentage of real income), whether positive or negative, were greater for small farmers than for larger farmers. In Egypt, Thailand, and Turkey, direct interventions taxed both small and large farmers during most of the period, although in Thailand the income effect was very small-less than 1.8 percent for all income groups. In all three countries, large farmers were taxed more than small farmers.

In almost all cases, indirect interventions worsened the income effects for rural households, reducing or obliterating the income gains from direct interventions, as in Brazil, Ghana, and Korea, or increasing the losses, as in most other countries. The indirect effects reduced the income losses for some periods and some income groups in Ghana (larger farmers) and to a much smaller extent in Thailand (all farm size groups).

Price interventions had a relatively larger real income effect on farm producers than on urban consumers. Direct price interventions had considerably more impact on the real income of larger farms (or wealthier rural households), whether these effects were positive (Koreaexcept 1980-83-and Portugal) or negative (Egypt and Turkey). Farms of all sizes were taxed heavily in Egypt, especially larger farms, which are more export-oriented and tend to sell a higher proportion of their production. Ghana was an exception, with small farmers gaining from 
direct price interventions because they produce more rice, which is protected, and larger farmers losing because they produce more coffee and cocoa, which are heavily taxed.

Where direct interventions protected farmers, as in Korea, richer farmers or households benefited more than poorer ones. In Portugal, direct interventions had almost no effect on the income of small and medium-size farms while benefiting larger farmers. Thailand was the only case in which the real income effects of both direct and total price interventions were negligible during 1960-84.

On the whole, the income effects for rural households were substantially higher and in the opposite direction from those for urban households in the same countries. Removing all price interventions would have brought real income benefits to farm households at all levels of living and by a substantial proportion of household income in Brazil (around 15 percent in 1980-83), Egypt (between 35 percent and 56 percent for all groups throughout 1964-85), Ghana (17 percent to 37 percent for larger farmers during 1962-76), and, to a lesser extent, Turkey (2.8 percent to 4.8 percent for all income levels during 1961-79). Because of the pattern of direct interventions, removing total price interventions would have reduced the real income of farmers in Korea (except 196269), Portugal (for larger farmers), and Ghana (small farmers in 1970-76).

\section{In the Long Term, the Poor Have Probably Lost Disproportionately}

In the long run, the net effect of price interventions may in many cases have been regressive. To the extent that the benefits from food subsidies were captured mainly by urban households - and predominantly employees in the government and formal sector-at the expense of the rural sector, the cost may have been a reduction in the real income of the rural poor and, indirectly, the urban poor in the informal sector. If taxing agriculture reduces rural demand for labor, rural employment and real wages will fall, leading to increased migration to the cities and increased competition for employment, and thus to a fall in income (or an increase in unemployment) in the informal urban sector as well. The net effect would thus be regressive since the bulk of the poor in developing countries are in rural areas, while the poor in urban areas are largely in the informal sector, which is unprotected by minimum wage or other labor legislation.

Studies of Brazil, Chile, and Colombia show that removing interventions would have raised the real income of landless labor, the poorest group in the rural sector and generally the poorest group in the economy. And by reducing rural migration, the removal of interventions might also have 
raised the income of the urban poor, although this effect is less clear because of the possible benefits of food subsidies for the urban poor.

In the long run, the cumulative net effect of price interventions on the real income of the poor depends on the combined effect of the very short-run impact on the consumer price index and the impact on overall economic growth, which affects employment and nominal income. Estimates of short-run effects for fourteen countries provide a rough indication of the direction of change in the real income of the poor as a result of price interventions.

On average, total interventions for the fourteen countries taxed agriculture at a rate of about 26 percent, resulting in an average annual loss in GDP growth of 1.1 percent, or 23 percent after twenty years. For the urban poor, static distributional gains from total interventions (the impact on the consumer price index) averaged 6.5 percent. Assuming a constant share of labor income in total income, the net effect (static gains plus cumulative impacts on growth) on the urban low-income group of total interventions from the early 1960 s to the early 1980 s was a real income loss of more than 15 percent.

For the urban poor in all countries except Egypt, the loss resulting from the negative impact on growth was higher than the static income gains from price interventions, so the urban poor lost over time. While these results suggest that substantial benefits would accompany the removal of price interventions, efforts to do away with food subsidies have faced strong resistance from urban consumers. The loss to urban consumers as a result of such reforms is immediate and easy to seewhile the benefits of higher growth appear only over time. In Egypt, Morocco, Zambia, and elsewhere, government attempts to remove food subsidies led to riots and forced a reversal of the reforms. True, it is misleading to associate agricultural price reforms with food riots. But riots can occur, especially if the country's macroeconomic situation requires a drastic reform with dramatic effect on food prices. The implication is to speed up the reform while the economic conditions do not yet require a dramatic rise in food prices.

Policy recommendation 8 . If a country wants to obtain the full benefit of reforming agricultural prices and trade, it should launch reforms in the marketing and distribution of agricultural inputs, outputs, and rural consumergoods - as well as complementary reforms in transport, communications, and land, labor, and credit markets.

Institutional and infrastructural weaknesses can limit the response of private investment and output to price reform. Producers are unlikely 
to respond strongly to a price increase given by a marketing board with inadequate infrastructure and human resources to efficiently market and transport inputs and output or with insufficient financial resources to buy the larger output generated by the price increase. To make reform credible, other measures would be needed to strengthen and liberalize marketing and transport. With quantitative restrictions in transport or marketing of inputs or output, price reform will essentially result in transfers between producers, consumers, and marketing boards but will have little impact, if any, on private investment and output. And when rural consumer goods are rationed, an increase in the price of agricultural goods may have a perverse effect, with output actually falling. Finally, efficient labor markets and domestic and international transport and communications systems are essential for the development of a dynamic agricultural export sector.

The breadth of price reforms and their credibility strongly influence the way producers respond to price changes. If price reform affects only a single product or a small group of products, the response for that product will tend to be large because of changes in output, but the aggregate response will be smaller than it would be if the reform had been more general. That means that reforming the policies that create high rates of indirect taxation, which affect all of agriculture, should result in a broader, more substantial response over time than reform of direct interventions alone.

Producers' expectations about whether the price change will last will also influence how much supply responds to a given price change. If producers believe that price changes are only temporary, they might increase the output of the annual crops whose prices increased by using more variable factors. But they would not increase investment-to raise productivity or to increase their output of tree crops - as they might if they believed the new prices would last, because they would not expect a higher return on their investment. The response would therefore be much more limited.

Many factors affect the credibility or expected longevity of the new set of prices that result from reform. If the prices of products subject to price control are increased once and for all in an inflationary environment, producers would expect the nominal price increase to erode in real terms - and they would have little incentive to increase output. Their response would be different if price controls were removed entirely.

Macroeconomic uncertainty also dampens the response to price reforms because it creates instability in relative incentives in the economy. When inflation is high and the real exchange rate is substantially overvalued, the rate of indirect taxation is high and highly variable. 
Removing direct price interventions may not lead to a large supply response under these conditions because of the general uncertainty and because the impact of nominal price changes on relative prices is hard to discern. To generate a substantial response by producers under these conditions, agricultural price reform would need to be accompanied by broader reform of macroeconomic policies.

Sometimes a poor response to price reform is related to the disparity between official prices and true incentives. Often, official prices do not reflect marginal incentives because some transactions are carried out at other prices. In Kenya, when the marketing board was unable to buy the entire output of beans produced in response to its official offer of higher prices, farmers had to wait months to get paid or had to sell some of their output on the domestic market at a lower price. In Ghana, the Cocoa Marketing Board often delayed payments because of corruption or lack of funds-issuing promissory notes or checks that farmers had difficulty cashing locally. Under these conditions, farmers may be responding to the lower market price rather than to the higher official price. The weak response to an increase in the official price does not mean that farmers do not respond to higher incentives - only that they realize that higher official prices do not always improve the incentives.

Institutional and infrastructural weaknesses can also limit the response of output to price reform. Producers are unlikely to respond strongly to a price increase given by a marketing board with inadequate infrastructure and human resources to efficiently market and transport inputs and output or with insufficient financial resources to buy the larger output generated by the price increase. To make reform credible, other measures would be needed to strengthen and liberalize marketing and transport.

The failure of poorer farmers to respond to input subsidies is also sometimes viewed as an indication of a low responsiveness to improved incentives in the agriculture sector. Often, however, small-scale farmers fail to take advantage of input or credit subsidies not because they are uninterested but because poorly designed programs make it difficult for them to do so-while allowing larger, better-connected farmers or agricultural processors to capture the subsidies. When small farmers do manage to receive subsidized fertilizer, they often receive it at the wrong time or receive a variety unsuited to their soils or crops. Similarly, farmers are often reluctant to use "subsidized" credit because of the high cost (in travel and time-consuming administrative requirements) of obtaining the funds.

Sometimes supply fails to respond as expected to, say, subsidized inputs, because the subsidies are not really reaching those the authorities 
thought they were reaching or intended to reach. In Brazil, subsidized credit went not to its intended recipients but to new "farmers," attracted to agriculture by the credit subsidy, which they used for land speculation. In Egypt, farmers often evaded controls intended to ensure that subsidized inputs were used in major food crops, using them instead in more profitable crops. Unsurprisingly, the response of the major food crops was considerably less than expected.

Under any of these conditions, the supply response is likely to fall considerably short of its potential. But if measures were taken to eliminate some of the constraints to improved input use and to ensure that prices reflected opportunities at the margin, the response to improved incentives would almost certainly be considerably larger than if prices did not reflect true opportunities and scarcities.

\section{What Happens If Many Developing Countries Reform Agricultural Prices at the Same Time?}

The assumption throughout this study is that international prices for farm products are given. But what happens if many countries stop taxing agriculture? Could that push down world prices?

The macroeconomic stabilization and trade liberalization under the structural adjustment programs of the 1980s undoubtedly reduced the indirect taxation of agriculture-with direct interventions on agricultural importables being positive and increasing in most developing countries. The total (direct and indirect) interventions for importables in developing countries are probably close to zero or slightly positive. Removing these interventions would thus have little impact on the world price.

Removing the tax on agricultural exports will undoubtedly lead to an expansion of output and to a reduction in consumption for many exportables that have been subject to a high tax. But the simultaneous removal of the total tax by all developing countries will dramatically suppress the world price only for a few traditional tropical products - such as coffee, cocoa, and palm oil-and punish the farmers growing tree crops.

For other exports, the effect would be much smaller because the extent of intervention has fallen in recent years-especially indirect intervention. The effect would also be smaller for four additional reasons. First, the share of developing countries in world trade of those products is significantly smaller than for tropical products. Second, the removal of trade barriers by developing countries will result in new markets and increased trade among developing countries and will constitute an additional source of demand. Third, economic reform by most developing countries—especially industrial trade liberalization-will put political 
pressure on countries belonging to the Organization for Economic Cooperation and Development to reciprocate by liberalizing agricultural trade. Such reciprocity could bring substantial income to developing countries. Fourth, another source of income related to removal of interventions is the potential for diversification. Agricultural price intervention has taxed exportables relative to importables. Removing these interventions will reallocate resources within agriculture toward the higher valued products and toward new products, including nontraditional exports. Countries that have opened their economies-such as Brazil, Chile, Kenya, Thailand, and Turkey-have diversified their agricultural exports. These possibilities for diversification are likely to reduce the adverse price effects of reform.

For commodities where the problem of demand constraint is relevant, the implications for policy are easily drawn from economic theory. The theory of second best states that any distortion should be attacked at the source. So any country that has market power on the world market for one of its exports (for example, cocoa in Côte d'Ivoire) may want to impose an optimal export tax or quota. This would reduce output and exports and increase the world price for the product. With an optimal export tax or quota, growth in output would not reduce welfare even if the price falls. Of course, an overvalued real exchange rate and industrial protection also tax agriculture-indirectly-reducing output and pushing up the world price. But such indirect taxation results in price distortions in the rest of the agricultural, industrial, and the nontradable sectors. So the policy recommendation is to remove indirect taxation-usually the largest element of the total taxation of agriculture-and use direct taxation (an export quota or tax) to deal with international market power.

For the few products for which developing countries can affect the world price, removing the indirect tax on agriculture would thus depress the world price. But an appropriate export tax or quota could offset this effect. And although lowering the domestic price, the export tax or quota would give farmers the incentive to diversify their output. It is true, however, that if all countries liberalize, they will have to deal with the complex issues of strategic interaction. That is, the appropriate export tax or quota in one country will depend on the level of the export tax or quota set by the other countries competing in the world market.

To sum up: developing countries will generally benefit from simultaneously removing agricultural price interventions. This removal will have a negligible effect on the world price, and it will improve the allocation of resources. For the few export products where developing countries have market power, appropriate export taxes or quotas should be imposed. 


\section{Price and Trade Reform Lessons}

Agricultural policy was a hot issue, and it remains so. But it is not yet focused. Governments often had contradictory goals. Some interventions increased farm prices while others depressed them. Governments taxed exports to earn government revenues but lost foreign exchange. They protected farmers producing food but also tried to protect consumers from high food prices. They subsidized credit and fertilizers to help small farmers but gave most of the transfer to the rural middle class and larger farmers. They invested in irrigation and research but taxed farmers with an overvalued exchange rate and higher prices for their consumer goods as a result of industrial protection. The result: many competing objectives pursued with price interventions-a blunt, indirect, and ineffective policy instrument for dealing with social objectives.

Agricultural price interventions were implemented predominantly through such restrictions as direct price regulations, customs clearance procedures, sanitary regulations, variable levies, discretionary import and export licensing, and others. All these instruments tend to be excessively complex and difficult to administer. These also tend to defy understanding by the public. To a large extent the public was kept in the dark about the level and extent of protection and taxation. Given this lack of transparency, economic agents did not react much to price gaps and rates of protection as such, and this reduced the political pressure for a more uniform treatment among subsectors.

A reform toward a less capricious pattern of agricultural price interventions seems warranted, based on policy instruments such as tariffs and explicit export taxes-which unlike quantitative restrictions, do not disguise the (hidden) income transfers but which do provide transparency on the policies. A dynamic, better integrated market strategy for agriculture requires a more visible and explicit system of price signals to reallocate resources and accelerate the output response.

The very high level of the prevailing indirect price interventions, and the political economy analysis in the various country studies suggests that government and farmers did not have a sense of these indirect effects which, paradoxically, overwhelmed the effects of the sectoral policies. Removing the indirect taxation to agriculture is a condition for more rapid agricultural growth.

Finally, a price reform also requires cost-effective redistributive instruments to ease the burden of the most vulnerable groups. And it requires a new revenue structure for the government, with less distortionary taxes replacing the current ones. 


\section{References}

Balassa, Bela. 1971. The Structure of Protection in Developing Countries. Baltimore: Johns Hopkins University Press.

Bhagwati, Jagdish N. 1978. Foreign Trade Regimes and Economic Development: Anatomy and Consequences of Exchange Control Regimes. Lexington, Mass.: Ballinger Press for the National Bureau of Economic Research.

Krueger, Anne O. 1978. Foreign Trade Regimes and Economic Development: Liberalization Attempts and Consequences. Lexington, Mass.: Ballinger Press for the National Bureau of Economic Research.

1983. Trade and Employment in Developing Countries, vol. 3, Synthesis. Chicago: University of Chicago Press.

Krueger, Anne O., Hal B. Lary, Terry Monson, and Narongchai Akrasanee. 1981. Trade and Employment in Developing Countries, vol. 1, Individual Studies. Chicago: University of Chicago Press.

Little, I. M. D., Tibor Scitovsky, and Maurice Scott. 1970. Industry and Trade in Some Developing Countries. London: Oxford University Press. 








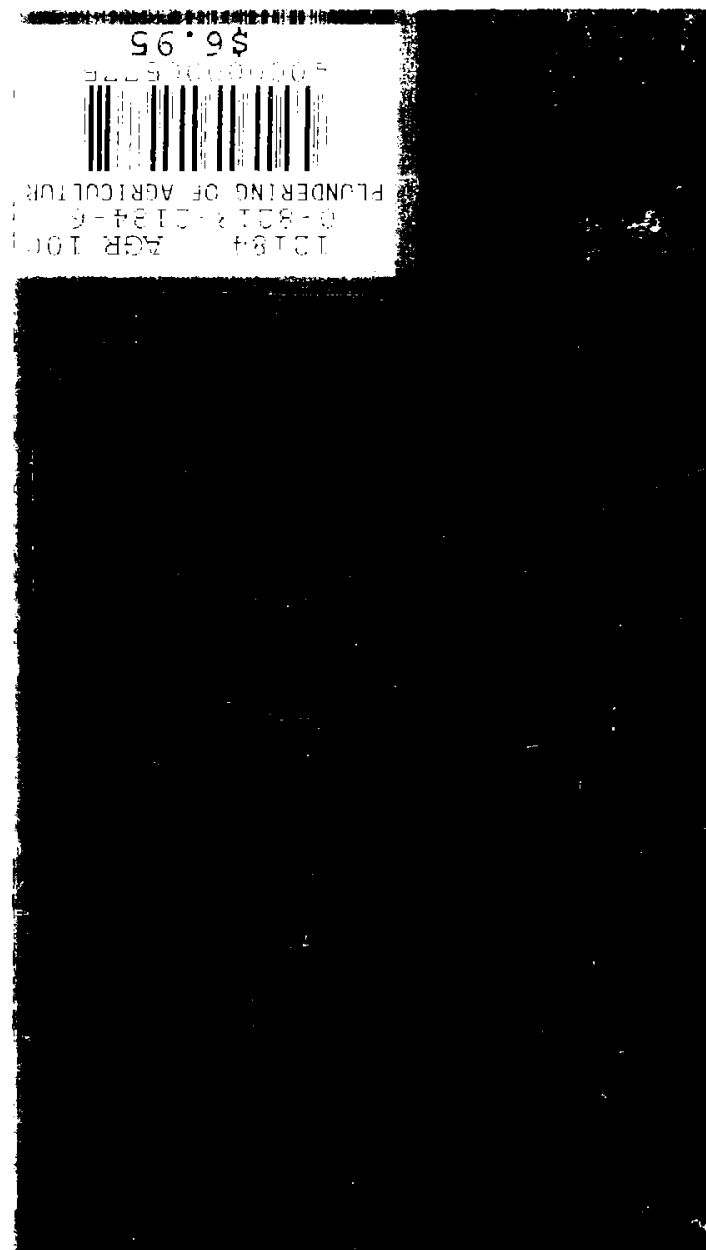

$s=$

$\therefore=1$

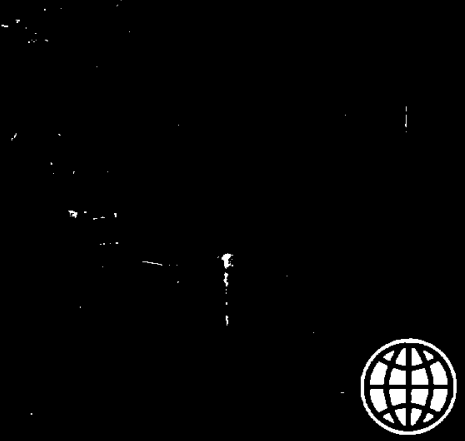

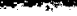

